\title{
When is a randomised controlled trial required: the theoretical domains framework approach
}

\author{
Marion Campbell ${ }^{1 *}$, Jill Francis ${ }^{2}$, Eilidh Duncan, Graeme MacLennan, Brian Cuthbertson³ ${ }^{3}$ SUDDICU Study Group ${ }^{1}$ \\ From 2nd Clinical Trials Methodology Conference: Methodology Matters \\ Edinburgh, UK. 18-19 November 2013
}

When evidence of a potentially promising intervention starts to accumulate it is often difficult to know whether the evidence is strong enough to move to promote widespread adoption or whether any, or further, randomised trials are required. We propose that the "Theoretical Domains Framework", or TDF, is a useful tool to guide whether further randomised trials require to be undertaken. The TDF is a theory-informed framework developed in the field of health psychology, that allows the systematic assessment of constructs likely to affect health professionals adoption/use of the intervention under consideration. It assesses twelve separate domains that may affect health professionals readiness to adopt a treatment or change their behaviour. Depending on the profile of responses to the TDF, decision rules can be generated to determine whether further effectiveness research is still required. We recently adopted the TDF approach in a critical care setting exploring whether further randomised trials of a particular treatment (selective decontamination of the digestive tract) were deemed to be required (and, if so, additional questions identified what particular aspects should be addressed). This mixed-methods international study involving research groups in the UK, Canada, Australia and New Zealand highlighted the usefulness of the TDF approach in providing an evidence-based judgement on whether a randomised trial should be initiated. We will explain the TDF approach, how it can be adopted to identify whether further trials are required, and demonstrate its use in practice.

\section{Authors' details}

${ }^{1}$ University of Aberdeen, Aberdeen, UK. ${ }^{2}$ City University, London, UK.

${ }^{3}$ Sunnybrook Health Sciences Centre, Toronto, Canada.

Published: 29 November 2013

doi:10.1186/1745-6215-14-S1-07

Cite this article as: Campbell et al:: When is a randomised controlled

trial required: the theoretical domains framework approach. Trials 2013 14(Suppl 1):O7.

'University of Aberdeen, Aberdeen, UK

Full list of author information is available at the end of the article

Submit your next manuscript to BioMed Central and take full advantage of:

- Convenient online submission

- Thorough peer review

- No space constraints or color figure charges

- Immediate publication on acceptance

- Inclusion in PubMed, CAS, Scopus and Google Scholar

- Research which is freely available for redistribution
C Biomed Central
C Biomed Central

@ 2013 Campbell et al; licensee BioMed Central Ltd. This is an Open Access article distributed under the terms of the Creative Commons Attribution License (http://creativecommons.org/licenses/by/2.0), which permits unrestricted use, distribution, and reproduction in any medium, provided the original work is properly cited. 